\title{
Meconium Stained Amniotic Fluid
}

National Cancer Institute

\section{Source}

National Cancer Institute. Meconium Stained Amniotic Fluid. NCI Thesaurus. Code

C113155.

Presence of meconium into amniotic fluid. 